\title{
A preliminary study on motivation and gender in CLIL and non- CLIL types of instruction
}

\author{
Almudena Fernández Fontecha \& ANDRÉs CANGA AlONSO* \\ Universidad de La Rioja
}

Received: 26/07/2012. Accepted: 09/04/2013.

\begin{abstract}
This paper sets out to enquiry about gender-based differences in motivation towards EFL in two different types of instruction, i.e. CLIL and EFL (non-CLIL). The study was carried out with $4^{\text {th }}$ Primary education Spanish students randomly selected from two mixed-gender schools in La Rioja (Spain). The results show that non-CLIL learners are significantly more motivated than CLIL learners. The non-CLIL girls are slightly more motivated than non-CLIL boys. However, CLIL boys are slightly more motivated than CLIL girls. Non-CLIL boys are more motivated than CLIL boys, and non-CLIL girls are more motivated than CLIL girls. These findings indicate that research on CLIL should closely take into account the way this methodological approach is implemented in a specific context since context-specific elements play a pivotal role in students' motivation towards EFL.
\end{abstract}

KEYWORDS: Sex/gender, motivation, CLIL, type of instruction, Primary education.

\section{RESUMEN}

Este artículo pretende investigar las diferencias de motivación hacia el aprendizaje de inglés como lengua extranjera en dos tipos diferentes de instrucción, es decir, en contextos AICLE y no-AICLE. El estudio se llevó a cabo con 62 estudiantes españoles de $4^{\circ}$ de educación primaria elegidos al azar de dos colegios mixtos de Logroño (La Rioja, España). El grupo AICLE estaba formado por 14 chicas y 17 chicos, mientras que el noAICLE lo constituían 18 chicos y 13 chicas en contextos no-AICLE. Los resultados muestran que los estudiantes no-AICLE están significativamente más motivados que sus compañeros AICLE. Las chicas no-AICLE están ligeramente más motivadas que chicos no-AICLE. Los chicos no-AICLE están más motivados que los chicos AICLE y las chicas no-AICLE que las chicas AICLE. Se apuntan diferentes razones para explicar dichos resultados.

PALABRAS CLAVE: Sexo/género, motivación, AICLE, tipo de instrucción, educación primaria.

*Address for correspondence: Almudena Fernández Fontecha. Departamento de Filologías Modernas, C/San José de Calasanz, 33, 26004 Logroño (La Rioja), Spain; e-mail: almudena.fernandez@,unirioja.es. 


\section{INTRODUCTION}

Content and Language Integrated Learning (CLIL) is an approach in which a foreign language is used as a tool in the learning of a non-language subject in which both the language and the subject have a joint role (Coyle, 2007; Mehisto, Marsh \& Frigols, 2008). The essence of CLIL is integration with a dual focus: "language learning is included in content classes (e.g. maths, history, geography [...], etc), and content from subjects is used in language learning classes" (Mehisto, Marsh and Frigols, 2008: 11). Content in CLIL will depend on the context of the learning instruction. It can range from the delivery of elements taken directly from a statutory national curriculum to a topic based on topical issues drawing together different aspects of the curriculum. Content in a CLIL setting could also be thematic, cross-curricular, interdisciplinary or focus on citizenship.

Content learning and its integration with language is complex and implies teachers and apprentices working together in a dynamic state where the whole is greater than the sum of the parts. Therefore, the social-constructivist model (Vygotsky, 1978) is associated with CLIL settings, since it focuses on interactive, mediated and student-led learning. This scenario requires social interaction between pupils and teachers, so that the former become cognitively engaged, which implies that they need to be aware of their own instruction through developing metacognitive skills such as learning to learn. They must be taught how to operate collaboratively and work effectively in groups. Therefore, for CLIL teaching to support effective understanding, it has to take into account not only students' knowledge and skills base, but also their cognitive engagement. On the basis of such an awareness can students' responsibility be promoted as a preliminary step towards the development of autonomy, and, ultimately, to the achievement of more successful learning outcomes (Pérez-Vidal, 2009).

Assuming that in CLIL settings it is necessary to progress systematically in both pupils' content and language learning and using, then using language to learn becomes as important as learning to use language. As a result, classroom communication - interaction between peers and teachers - is at the core. There is also growing recognition that dialogic forms of pedagogy - that is, "where learners are encouraged to articulate their learning" (Coyle, Hood and Marsh, 2010: 35) - are potent tools for securing students' engagement, and understanding. Focusing teaching on quality discourse understanding between students, and between learners and teachers - where pupils have different opportunities to discuss their own learning with other peers as it progresses, where feedback is integrated into classroom discourse and where apprentices are encouraged to ask as well as answer questions. The challenge in the CLIL setting is that trainees will need to engage in dialogic interactions by using the vehicular language.

This interaction between teachers and pupils is supposed to foster learner motivation (Lasagabaster, 2011) at Secondary education. However, to our knowledge no studies have conducted with Spanish Primary students regarding gender and motivation in CLIL and non- 
CLIL (EFL) settings: For this reason, in the following sections this paper will relate motivation and gender in the foreign language and CLIL classroom.

\section{REVIEW OF THE LITERATURE}

\subsection{Motivation and gender in foreign language learning}

Both motivation and gender are recognized as relevant variables in foreign language learning (FL). A large number of studies have identified a positive link between motivation and scores in foreign language learning (Bernaus \& Gardner, 2008; Csizér \& Dörnyei, 2005; FernándezFontecha, 2010b; Gardner, 2007; Masgoret \& Gardner, 2003; Schmidt \& Watanabe, 2001; Yu \& Watkins, 2008).

There are several models of motivation and language learning. Gardner \& Lambert (1972), for example, developed the widely known Socio-Psychological Model, which covers two types of motivation: integrative and instrumental motivation. The former type corresponds to learners' willingness to learn the language so as to become part of the target language community, whereas the latter refers to learners' desire to gain FL proficiency for practical purposes. Another well-known framework is the Self-Determination Theory (Deci \& Ryan, 1985; Noels, 2001; Noels, Pelletier, Clément \& Vallerand, 2000), which addresses two further types of motivation: (a) extrinsic motivation, which focuses on the external factors that influence FL learning, and (b) intrinsic motivation, which refers to the interest generated by the activity itself. Of these types, intrinsic motivation seems to produce the most positive effect in language learning (Gardner, Lalonde \& Moorcroft, 1985; Hernández, 2006; Masgoret \& Gardner, 2003; Oller, Hudson \& Liu, 1977; Tremblay \& Gardner, 1995).

Concerning learners' gender, overall, a great bulk of studies conclude that there is some connection between this variable and language scores (Hyde \& Linn, 1988; Kiss \& Nikolov, 2005; Maitland et al., 2004; Stumpf, 1995), being girls superior to boys. This superiority is detected quite early in first language acquisition and tends to disappear with age. In foreign language acquisition, with some exceptions (e.g. Phatiki, 2003; Scarcella \& Zimmerman, 1998) this general tendency is also identified. For example, in studies conducted on FL vocabulary acquisition, females prove superior in a number of productive tasks (Jiménez \& Moreno, 2004; Jiménez \& Ojeda, 2008b), although no conclusive evidence is obtained on receptive vocabulary (Agustín \& Terrazas, 2008).

The relationship between learners' motivation and gender has been widely examined in the framework of foreign language learning. Again, the tendency is that girls are more motivated towards foreign language learning than boys (Dabbagh \& Khajehpour, 2011; Henry \& Apelgren, 2008; Kissau, 2006; Mills, Pajares \& Herrón, 2007; Mori \& Gobel, 2006; Norton, 2000; Spolsky, 1989; Wikeley \& Stables, 1999). On the contrary, no differences based on gender are identified in other studies (Lasagabaster, 2003; Ludwig, 1983). 
The literature points to some reasons for this typical female dominance in linguistic tasks and motivation towards foreign language learning. Some of them address some genderrole stereotyped socialization according to which boys and girls would opt for different sets of academic fields or subjects (Wigfield et al., 2006: 18-20). As an example, in a survey by the Spanish Statistical Institute on the 2010 University Entrance Exam, 53.1\% of the girls versus $38.8 \%$ of the boys chose the branch of Humanities and Social Sciences; on the other hand, $59 \%$ of the boys versus $43.2 \%$ of the boys opted for Science and Technology studies (Instituto Nacional de Estadística, 2010). The tendency in Europe is the same (Eurostat Newsrelease, 2009). Some other reasons for females' superiority may imply biological differences between males and females in performing language-related tasks, such as vocabulary retention (Hartshorne \& Ullman, 2006; Ullman, 2001, 2004, 2005; Ullman et al., 2008). It seems undeniable that in order to offer a plausible explanation for this female advantage in language learning, one should consider separately the dynamic nature of motivation and foreign language learning, and look into the particularly complex relationship between both.

\subsection{Motivation and gender in CLIL}

The With the advent of the CLIL approach in the European context, different studies have begun to examine the relationship between motivation and FL achievement in CLIL and nonCLIL contexts. In some of these studies, the gender variable is also considered. Overall, this research has concluded that learners in CLIL settings show higher motivation than learners in non-CLIL settings at Secondary education (Lasagabaster, 2011; Murtagh, 2007; SeikkulaLeino, 2007). In this line, Dalton-Puffer (2008) points to the positive affective effects of CLIL, which seem to make learners lose their inhibitions to use the FL spontaneously, among other reasons.

With regard to students' attitude towards language learning and gender, there is a scarcity of research in different contexts of FL instruction. If we look back to studies grounded in the Canadian Immersion programmes, a general trend is identified: bilingual programmes have some kind of levelling effect on gender-based differences in FL achievement favouring boys' attainment and motivation towards the foreign language (Baker $\&$ MacIntyre, 2000). More recently, Merisuo-Storm (2007) reached the same conclusion for a group of Primary education students in the Finnish context.

Counterevidence is also available to prove that females keep on outperforming males and show more positive attitudes towards the FL both in CLIL and non-CLIL models. As an example, in a series of studies conducted in the Basque country, Lasagabaster (2008) and Lasagabaster and Sierra (2009) found that female Secondary learners performed better than male Secondary learners in CLIL type provision. It seems that weaker versions of CLIL or bilingual education do not have the same vanishing effect as stronger versions such as Immersion (Lasagabaster \& Sierra, 2009:13). 
In light of the reviewed literature between FL proficiency and motivation together with the purported benefits of CLIL, the present study attempts to contribute to the exploration of the influence of the type of instruction on the motivational levels of a group of Spanish Primary male and female learners of English as a Foreign Language (EFL). More specifically, we intend to explore (1) learners' general motivation levels, as well as intrinsic and extrinsic types, in CLIL and non-CLIL instruction; and (2) if there are any gender-based differences in learners' general, intrinsic and extrinsic motivation in each type of instruction.

\section{METHODOLOGY}

\subsection{Participants}

The subjects of this study were 62 8-9 year-old $-4^{\text {th }}$ Primary education Spanish students. They were randomly selected from two mixed-gender schools located in Logroño (La Rioja, Spain) with similar sociocultural and economic backgrounds. The participants were divided into two groups according to the kind of instruction they received at school. The non-CLIL group was formed by 31 learners (18 girls and 13 boys), whereas the CLIL group involved 31 learners (14 girls and 17 boys). The students in the CLIL group belonged to the PILC project (Proyectos de Innovación Lingüistica en Centros - School Language Innovative Projects), a regional plan in which part of a content subject is taught through English.

At the time that this research was conducted, both groups had received 419 hours of instruction in English as a foreign language, but the CLIL group had also been taught Natural Sciences through the medium of English for 281 hours.

\subsection{Instruments and procedures}

A part of an adapted version of Gardner's (1985) attitude/motivation test battery (A/MTB) was implemented to measure boys and girls perceptions about English. A/MTB sets out to measure intrinsic and extrinsic motivation towards EFL in both genders using a semantic differential technique of seven-point bipolar rating scale using seven pairs of bipolar adjectives. These adjectives are introduced with the phrase "Considero que el inglés es...". The pairs 'ugly'/'nice', 'attractive'/'unattractive', 'pleasant'/'unpleasant', and 'interesting'/'boring' were chosen to measure intrinsic motivation, whereas extrinsic motivation was tested by means of the bipolar pairs 'necessary'/'unnecessary', 'important'/'unimportant', and 'useful'/'useless'. This part of Gardner's (1985) questionnaire has been already used in studies in the Basque Country (e.g. Lasagabaster and Sierra, 2009) and in research conducted with students who belonged to the same sociocultural and educational background as the sample in this research (see Fernández Fontecha, 2010b; Fernández Fontecha \& Terrazas Gallego, 2012). 


\section{RESULTS}

In this analysis we distinguish three types of scores: (1) mean score in general motivation without defining types of motivation, (2) mean score in intrinsic motivation, and (3) mean score in extrinsic motivation.

In order to get a general idea of how motivated the sample was, we established three levels of general motivation according to the subjects' scores in the aforementioned part of Gardner's test: level 1 (low motivation marks: 1.0 to 3.0), level 2 (medium motivation marks: 3.01 to 5.0), and level 3 (high motivation marks: 5.01 to 7.0 ). Figure 1 shows that most learners in both groups were highly motivated $(\mathrm{N}=41,67.2 \%), 31.1 \%(\mathrm{~N}=19)$ were motivated at level 2 and $1.6 \%(\mathrm{~N}=1)$ was motivated at level $1(1.0-3.0)$.

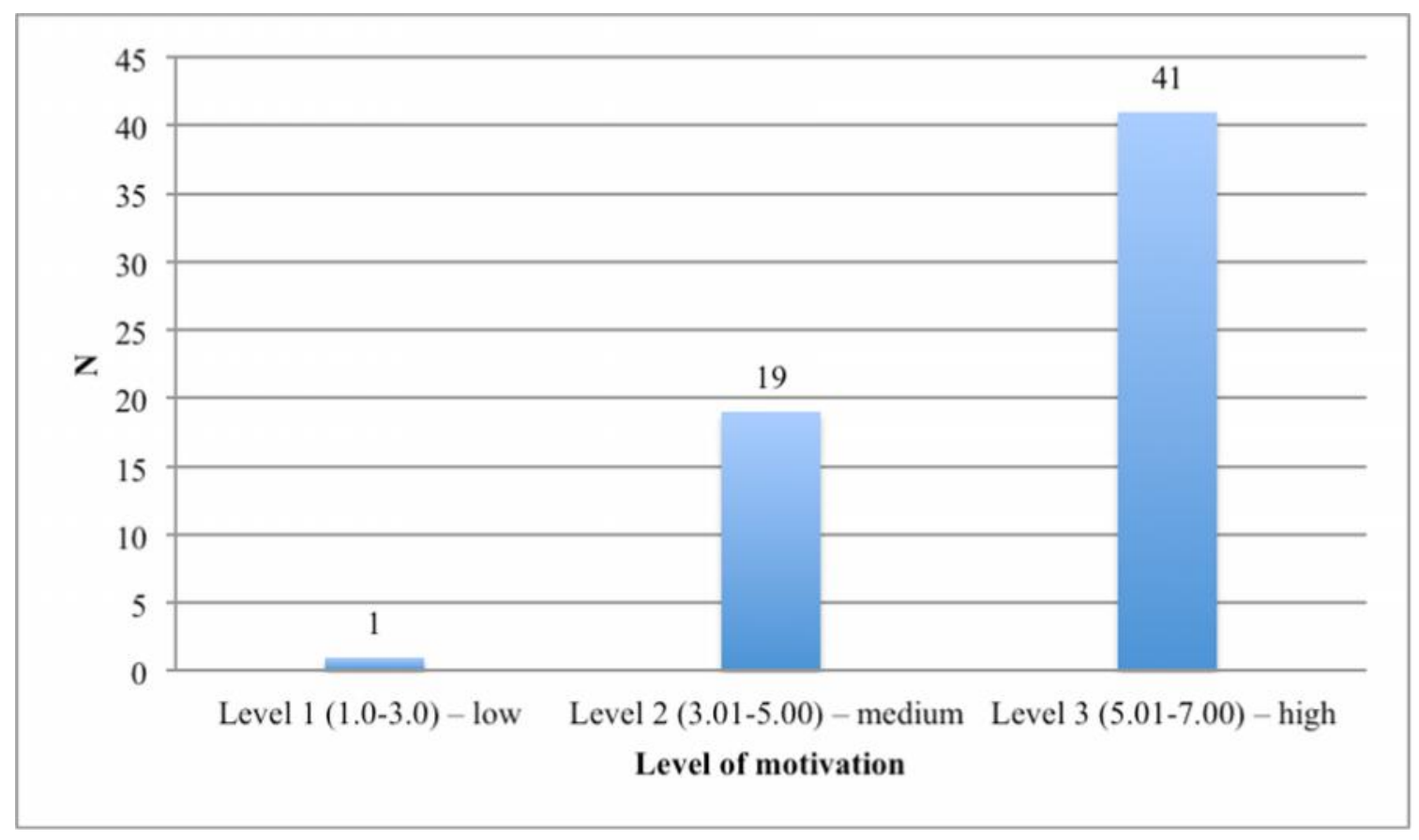

Figure 1. Descriptive statistics: number of subjects per level of motivation

Figure 2 shows that mean motivation together with the two types of motivation was higher in the EFL group. We also found that subjects in both groups are more extrinsically than intrinsically motivated. We identified a higher variation in mean, intrinsic and extrinsic motivation scores in the CLIL group, as the Standard Deviation values imply (Table 1). 


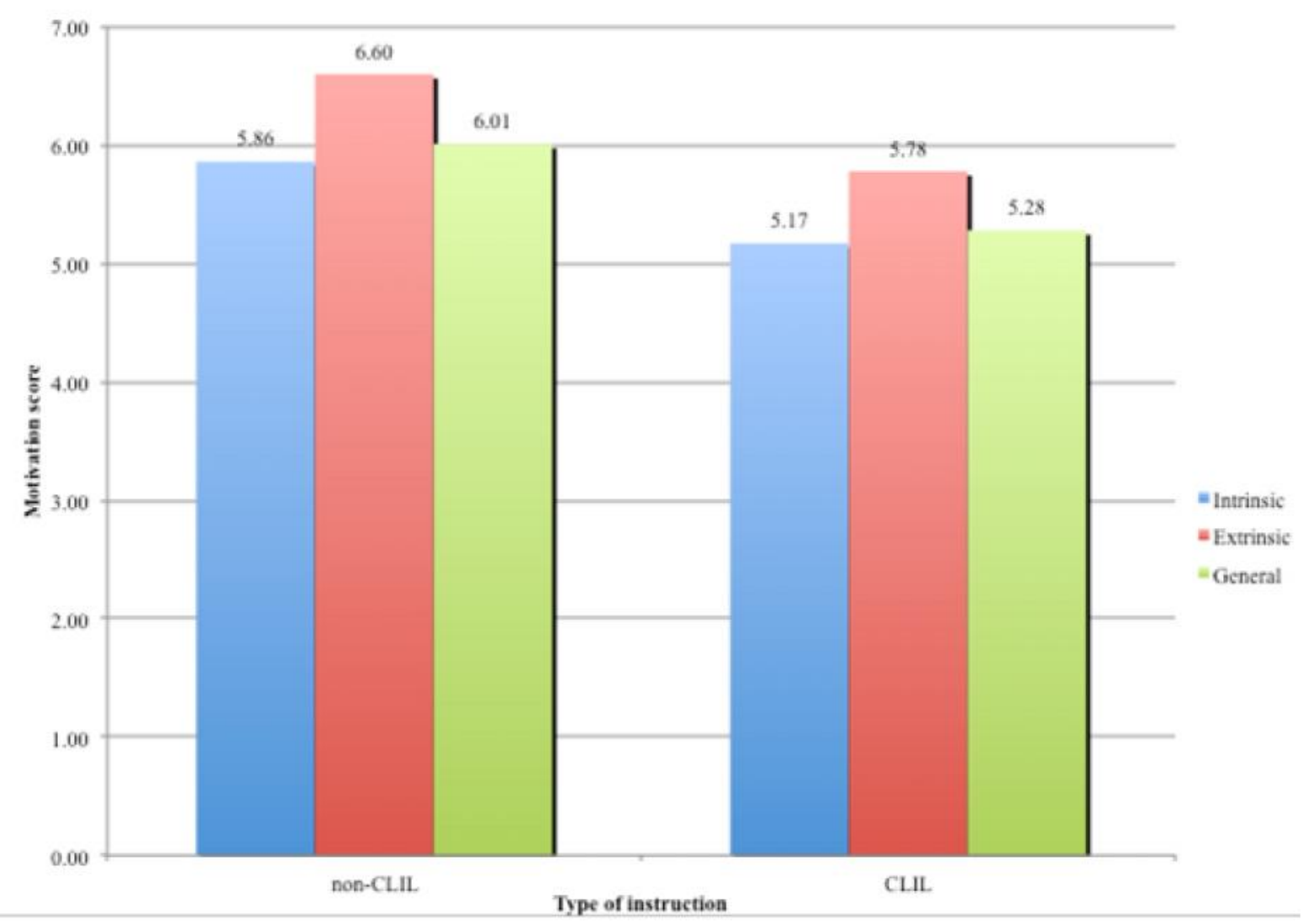

Figure 2. Levels of general motivation per type of instruction

\begin{tabular}{llrrrr}
\hline Type of instruction & Motivation & Min. & Max. & Mean & SD \\
\hline EFL & Intrinsic & 3.25 & 7.00 & 5.86 & 1.05 \\
& Extrinsic & 3.67 & 7.00 & 6.60 & .78 \\
& General & 4.13 & 7.00 & 6.02 & .86 \\
CLIL & Intrinsic & 2.50 & 7.00 & 5.17 & 1.20 \\
& Extrinsic & 3.00 & 7.00 & 5.78 & 1.24 \\
& General & 3.00 & 7.00 & 5.28 & 1.07 \\
\hline
\end{tabular}

Table 1. Descriptive statistics: levels of motivation per type of instruction

A t-test revealed that data on the motivation variable were not normally distributed. Hence, we applied the non-parametric Mann-Whitney-Wilcoxon test (MWW) and Kolmogorov-Smirnov test (K-S). As Table 2 evinces, statistically significant differences are found with regard to the mean motivation of EFL and CLIL learners (MWW: p-value = 0.006; K-S: p-value $=0.047$ ). Similarly, at the same significance level, statistically significant differences are identified concerning the two types of motivation in both groups (intrinsic motivation: $\mathrm{MWW}$ : $\mathrm{p}$-value $=0.026$; K-S: $\mathrm{p}$-value $=0.027$; extrinsic motivation: $\mathrm{MWW}: \mathrm{p}$ value $=0.004 ; \mathrm{K}-\mathrm{S}: \mathrm{p}$-value $=0.013$ ). 


\begin{tabular}{llll}
\hline & Intrinsic & Extrinsic & General \\
\hline Mann-Whitney U & 311 & 278.5 & 276 \\
Wilcoxon W & 776 & 743.55 & 741 \\
Z & -2.23 & -2.88 & -2.73 \\
p-value & $\mathbf{. 0 2 6}^{*}$ & $\mathbf{0 0 0} * *$ & $\mathbf{. 0 0 6 * *}$ \\
Kolmogorov-Smirnov Z & 1.47 & 1.59 & 1.37 \\
p-value & $\mathbf{. 0 2 7 *}$ & $\mathbf{. 0 1 3 *}$ & $\mathbf{. 0 4 7 *}$ \\
\hline
\end{tabular}

Table 2. Inferential statistics: mean motivation and types of motivation $\left(* \mathrm{p}<0.05,{ }^{* *} \mathrm{p}<0.01\right)$

With regard to the level of general motivation according to the gender variable, Table 3 shows that overall both girls and boys are highly motivated. In general, there is not much difference between girls' and boys' mean, intrinsic and extrinsic motivation (girls: 5.68 vs. boys: 5.62) (Table 6). Both males and females follow a quite similar pattern with respect to the relationship between the two types of motivation, being extrinsic higher than intrinsic motivation (Figure 3).

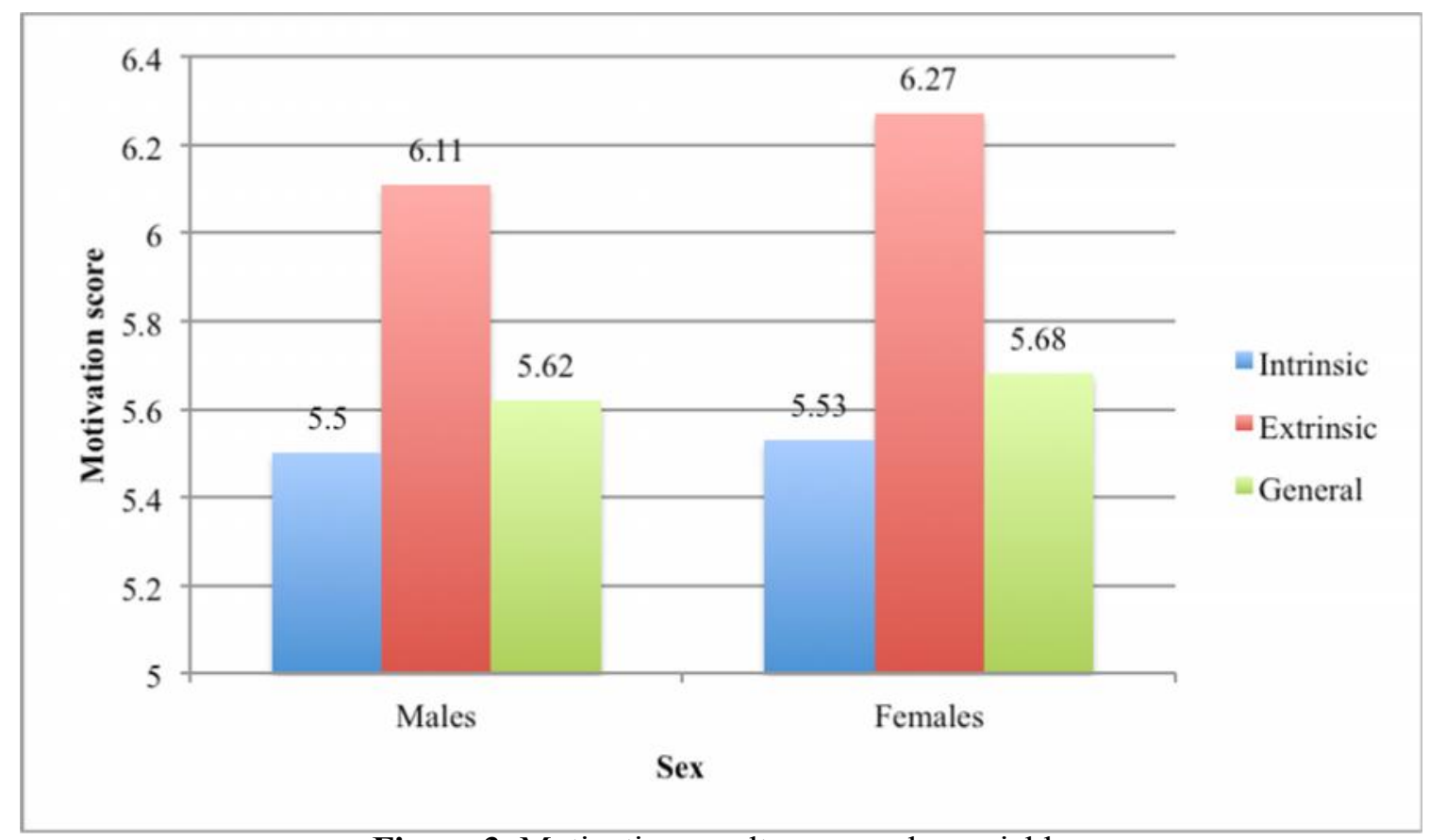

Figure 3. Motivation results per gender variable

\begin{tabular}{llrrrrr}
\hline Gender & Motivation & $\mathbf{N}$ & Min. & Max. & Mean & S.D. \\
\hline Males & Intrinsic & 30 & 3.50 & 7.00 & 5.51 & 1.11 \\
& Extrinsic & 30 & 3.67 & 7.00 & 6.11 & 1.20 \\
& General & 30 & 3.63 & 7.00 & 5.62 & .99 \\
& Valid N & 30 & & & & \\
\hline Females & Intrinsic & 31 & 2.50 & 7.00 & 5.53 & 1.24 \\
& Extrinsic & 31 & 3.00 & 7.00 & 6.28 & 1.02 \\
& General & 31 & 3.00 & 7.00 & 5.69 & 1.08 \\
& Valid N & 31 & & & & \\
\hline
\end{tabular}

Table 3. Descriptive statistics: motivation results per gender variable 
Tables 4 and 5 detail results as regards (1) same gender and different type of instruction and (2) same type of instruction - different gender as follows:

Concerning (1) same gender - different type of instruction results, we observe that in mean motivation as well as in intrinsic and extrinsic motivation, boys in the EFL group surpassed boys in the CLIL group, and, likewise, girls in the EFL group surpassed girls in the CLIL group. Concerning the results on (2) same type of instruction - different gender, EFL girls (6.74) outperformed EFL boys (6.41) in mean motivation whereas CLIL boys (5.88) overtook CLIL girls (5.64). With regard to the types of motivation, EFL boys' intrinsic motivation (5.89) was higher than EFL girls' (5.82) being this result not statistically significant. Similarly in the CLIL group, boys' level of intrinsic motivation (5.20) was found to be slightly higher than girls' (5.12). With respect to extrinsic motivation, EFL girls (6.74) achieved the highest level versus EFL boys (6.41), whereas CLIL boys (5.88) outperformed CLIL girls (5.64). None of these findings were statistically significant (Table 6).

\begin{tabular}{lllrrrrr}
\hline Gender & $\begin{array}{l}\text { Type of } \\
\text { instruction }\end{array}$ & Motivation & N & Min. & Max. & Mean & \multicolumn{2}{c}{ S.D. } \\
\hline Males & EFL & Intrinsic & 13 & 4.00 & 7.00 & 5.89 & 1.03 \\
& & Extrinsic & 13 & 3.67 & 7.00 & 6.41 & 1.11 \\
& & General & 13 & 4.13 & 7.00 & 5.94 & .98 \\
& & Valid N & 13 & & & & \\
& \multirow{2}{*}{ CLIL } & Intrinsic & 17 & 3.50 & 7.00 & 5.21 & 1.11 \\
& & Extrinsic & 17 & 4.00 & 7.00 & 5.88 & 1.25 \\
& & General & 17 & 3.63 & 7.00 & 5.38 & .95 \\
& & Valid N & 17 & & & & \\
\multirow{2}{*}{ Females } & EFL & Intrinsic & 18 & 3.25 & 7.00 & 5.83 & 1.09 \\
& & Extrinsic & 18 & 6.00 & 7.00 & 6.74 & .39 \\
& & General & 18 & 4.38 & 7.00 & 6.08 & .79 \\
& & Valid N & 18 & & & & \\
& & Intrinsic & 13 & 2.50 & 7.00 & 5.12 & 1.36 \\
& CLIL & Extrinsic & 13 & 3.00 & 7.00 & 5.64 & 1.27 \\
& & General & 13 & 3.00 & 7.00 & 5.15 & 1.23 \\
& & Valid N & 13 & & & & \\
\hline
\end{tabular}

Table 4. Descriptive statistics: levels of motivation per type of instruction and gender

\begin{tabular}{lllll}
\hline Results & & General & Intrinsic & Extrinsic \\
\hline $\begin{array}{l}\text { Same gender }- \\
\text { different type of } \\
\text { instruction }\end{array}$ & Males & EFL $>$ CLIL & EFL $>$ CLIL & EFL $>$ CLIL \\
& Females & EFL $>$ CLIL & EFL $>$ CLIL & EFL $>$ EFL \\
$\begin{array}{l}\text { Same type of } \\
\begin{array}{l}\text { instruction }- \\
\text { different gender }\end{array}\end{array}$ & $\begin{array}{l}\text { EFL group } \\
\text { CLIL group }\end{array}$ & $\begin{array}{l}\text { Females }>\text { Males } \\
\text { Males }>\text { Females }\end{array}$ & Males $>$ Females & Females $>$ Females \\
\hline
\end{tabular}

Table 5. Summary of results 
It is interesting to note that, with the exception of intrinsic motivation levels, EFL females achieve the highest levels of motivation of the four groups of students whilst CLIL females attain the lowest levels of motivation of these groups (Figure 4).

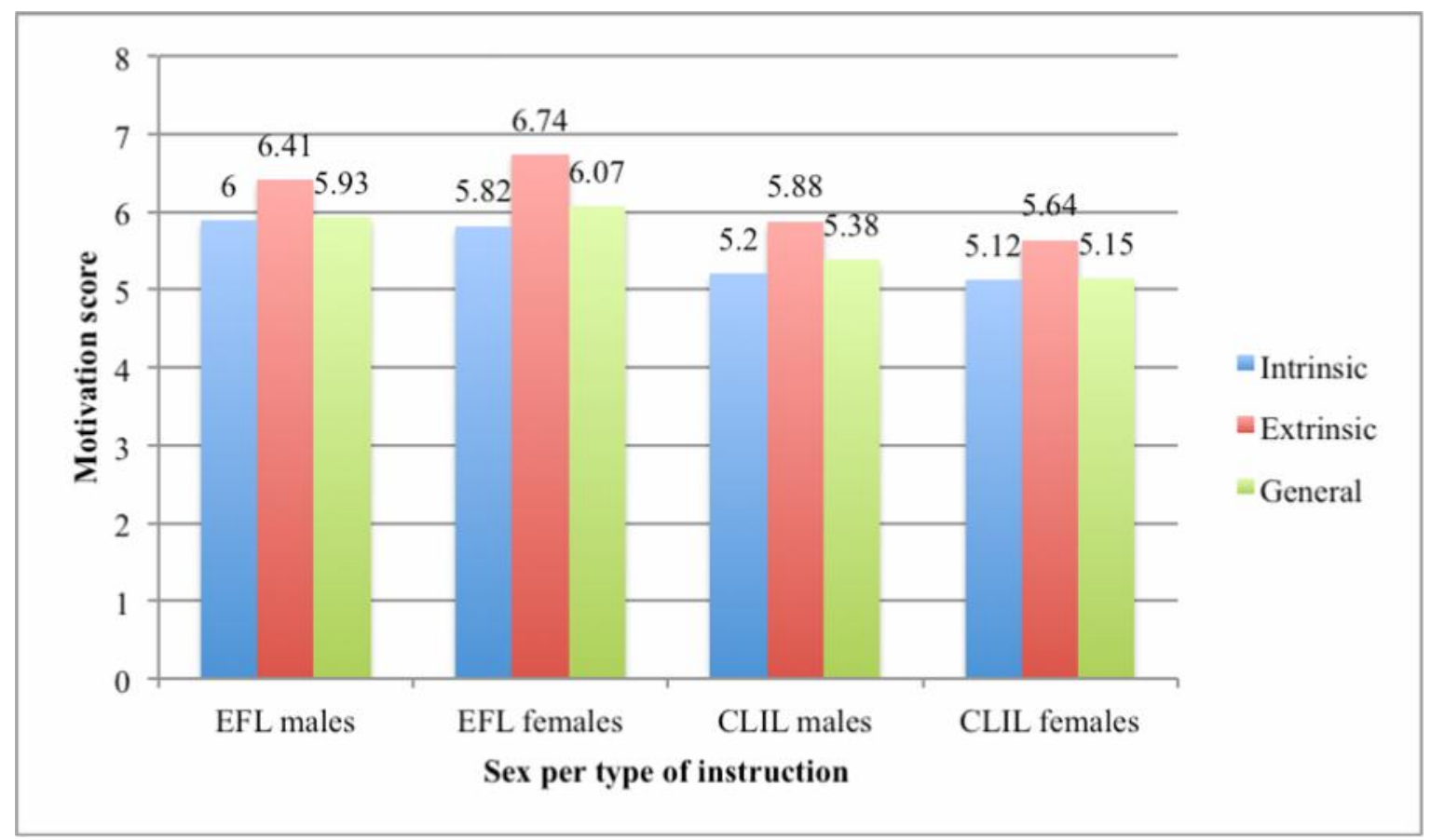

Figure 4. Levels of motivation per type of instruction and gender

\begin{tabular}{lccc}
\hline & Intrinsic & Extrinsic & General \\
\hline Mann-Whitney U & 443.50 & 463.50 & 438 \\
Wilcoxon W & 908.50 & 928.50 & 903 \\
Z & -.312 & -.023 & -.390 \\
p-value & $\mathbf{. 7 5 5}$ & $\mathbf{. 9 8 2}$ & $\mathbf{. 6 9 6}$ \\
Kolmogorov-Smirnov Z & .361 & .525 & .495 \\
p-value & $\mathbf{. 9 9 9}$ & $\mathbf{. 9 4 6}$ & $\mathbf{. 9 6 7}$ \\
\hline
\end{tabular}

Table 6. Inferential statistics: general motivation and types of motivation per gender and instruction

\section{DISCUSSION}

The first research question of this study addresses learners' levels of motivation in CLIL and non-CLIL contexts. Although all learners were highly motivated, contrary to research on CLIL and motivation (Lasagabaster, 2011; Murtagh, 2007; Seikkula-Leino, 2007) this research identifies statistically significant differences in terms of learners' motivation towards English as a Foreign Language in favour of the non-CLIL group. This result involves general motivation as well as intrinsic and extrinsic types. Despite these differences, the pattern in both groups regarding the types of motivation is similar: extrinsic motivation is higher than intrinsic motivation in both cases. We are aware of the fact that in order to give a complete 
view of the effect of the type of instruction, learners' levels of motivation should have been measured in both groups at the beginning of their instruction. In any case, in the interpretation of these results, a miscellany of factors that, among others, cover learners' age, CLIL methodological practices, and the additional time in the foreign language, should be considered. One fairly obvious explanation albeit a mundane one is that the extra load involved with CLIL simply bores and demotivates younger learners. We should note that the CLIL group received almost a third part of the total instruction time in the foreign language, i.e. 281 hours of instruction more than the non-CLIL group.

The CLIL group had been instructed in a Type B - PILC Project (Proyectos de Innovación Lingüística en Centros), in which part of a subject (Natural Sciences) is been taught in English. Although no classroom observation is included in the present study, we have some reservations about the way this programme has been planned from the official spheres. As an example, teachers involved in this study were required to hold a CEFR (Common European Framework of Reference for Languages) B1 level in EFL (Gobierno de La Rioja, 2004, 2005, 2009), which, in our view, is insufficient to develop any type of CLIL as exemplified in the description of the level. According to this CEFR level, the user "Can understand the main points of clear standard input on familiar matters regularly encountered in work, school, leisure, etc. Can deal with most situations likely to arise whilst travelling in an area where the language is spoken. Can produce simple connected text on topics which are familiar or of personal interest. Can describe experiences and events, dreams, hopes and ambitions and briefly give reasons and explanations for opinions and plans" (Council of Europe, 2001: 24).

In line with this not so optimistic perception on PILC provision, concerning language learning results under this type of programme, Fernández Fontecha (2010a) accounts for one research study conducted in this region by Jiménez and Ojeda (2008a), where a non-CLIL Primary group of students outperformed a CLIL group in a lexical availability task and a cloze test. However, we cannot offer any further conclusion of this programme in the Autonomous Community of La Rioja regarding language achievement since its provision has barely yielded any language learning results. All in all, further research is needed to explore the actual conditions of PILC provision and the methodology, teaching procedures and materials followed in the classroom.

Another possible reason to account for these results could be that students at this early age may not be aware of the importance of learning a foreign language. What is more, some of them may have learning problems regarding foreign language instruction, or even first language learning. Thus, the fact of learning a content subject in a language that is not their mother tongue together with the cognitive load that this subject already has may contribute to increase the difficulty of learning the subject and, as a result, their motivation may decrease.

Recent research has concluded that Secondary CLIL students outperform EFL students regarding motivation towards FL learning since the former are found to be at a more 
developed cognitive stage (Lasagabaster, 2011) - an aspect in current CLIL research which has received a strong criticism by Bruton (2011). Anyway, whether CLIL learners enter CLIL instruction with a higher level of cognition or not, cognition, and also motivation, are considered key issues in CLIL instruction. This fact leads to the idea that larger exposure to CLIL environments may help increase cognition along with motivational levels. Based on the result obtained in the present study and due to the fact that the CLIL informants of our sample are Primary learners in their 4th year of CLIL instruction, some follow-up research should be carried out in order to ascertain the relationship between age, CLIL instruction and its effect on motivation. More specifically, longitudinal studies contrasting learners' motivation at different educational levels as well as the relationship of CLIL and non-CLIL learners' mean motivation and types of motivation with L2 achievement will be helpful to come to further conclusions.

In the second research question of the present study we aim at identifying any genderbased differences in learners' general, intrinsic and extrinsic motivation. In both groups, boys and girls are very motivated, being girls more motivated than boys in general motivation, intrinsic and extrinsic motivation. However, although this result is consistent with a large body of research conducted on the effect of gender and motivation on FL learning, as noted in the review of the literature aforementioned, it is not statistically significant.

Although they are non-statistically significant results, a closer look into the motivation scores of boys and girls in each type of instruction reveals that boys and girls in the non-CLIL group are more motivated than boys and girls in the CLIL group. It is worth mentioning here that, against most studies that inquire the gender-motivation relationship in foreign language learning, males are slightly more motivated than girls in the CLIL group. This may imply that the subject matter has some role to play in attracting learners' attention despite its being taught in a foreign language. In this case, the subject was Natural Sciences, which, as explained in the review of the literature, is somehow considered a male subject. The peculiarity in the context of this study is that this subject is taught through a stereotypically female subject (EFL). Further investigation would be required so as to investigate the effect of the subject matter in learners' levels of motivation in CLIL instruction.

Whatever the reasons of this result, one could explain that the very slight differences between the motivation levels of boys and girls in the CLIL group are in line with research on attitudes of males and females in bilingual education that credits some vanishing effect on gender-related differences in Foreign Language achievement (Baker and MacIntyre, 2000; Merisuo-Storm, 2007). Yet, it is essential to remember that counterevidence is provided in studies conducted in the Spanish context by Lasagabaster (2008) and Lasagabaster and Sierra (2009), which conclude that in weaker versions of CLIL, as this PILC project definitely is, this leveling gender effect is not perceived. 


\section{CONCLUSION}

In the present study we have attempted to shed some light on motivational and gender factors in two different instructional contexts: CLIL and EFL. Two similar groups of Primary learners have been tested on motivation. Against previous research on the topic, this investigation concludes that non-CLIL learners are more motivated than CLIL learners. Several reasons have been pointed out to offer a plausible explanation for this fact, among them, the type of CLIL that this group of learners has been exposed to. At this point what this study reminds us of is that research on CLIL should closely take into account the way this instructional type is implemented in a specific context since, despite the common methodology underlying the approach, a myriad of context-specific elements play a role in defining the implementation of CLIL.

Therefore, future lines of research are also required to analyze the teaching procedures followed in both types of instruction (CLIL vs. non-CLIL) so as to identify the reasons for these findings. The role of the teacher, the methodology implemented, their teaching procedures along with the materials used are elements of critical importance for the learning outcomes and the resulting affective factors.

The second main result of this research addresses females' higher levels of motivation, an expected result if we consider previous results on gender in foreign language acquisition. The not so expected result is the fact that CLIL males obtain higher motivational levels than the CLIL females, although we should add that the difference between both levels is very small. The reason pointed out for this result considers the characteristics of the content subject, i.e. Natural Science, taught in the English language, as it may be generally considered more attractive for boys than for girls. This idea opens the way for further research on the effect of the CLIL subject on boys and girls' attitudes towards the L2 and their L2 achievement, among others.

Finally, we should comment on the need of studies with larger samples of learners in CLIL instruction in order to get more accurate results concerning motivation and other affective factors relevant in FL learning. Motivation is a very complex variable to be measured conveniently and, given this difficulty, different tests could be used in order to offer a more complete picture about this variable.

\section{ACKNOWLEDGEMENTS}

This study is part of the research project "Factores individuales y contextuales en la adquisición y desarrollo de la competencia léxica en inglés como lengua extranjera" funded by the Spanish Ministerio de Ciencia e innovación (Grant Ref. No: FFI2010-19334/FILO). We are also very thankful to our statistician Montserrat San Martin for providing us with very valuable statistical assistance and helpful insights into data interpretation. Any remaining errors are our own. 


\section{REFERENCES}

Agustín, M. P. \& Terrazas, M. (2008). Gender differences in receptive vocabulary size in EFL primary school learners: A longitudinal study. Paper presented at the XXXII AEDEAN. Conference, University of Palma de Mallorca, November, 13-15.

Baker, S. C. \& MacIntyre, P. D. (2000). The role of gender and immersion in communication and second language orientations. Language Learning, 50, 311-341.

Bernaus, M. \& Gardner, R. C. (2008). Teacher motivation strategies, student perceptions, student motivation, and English achievement. The Modern Language Journal, 92(3), 387-401.

Bruton, A. (2011). Is CLIL so beneficial, or just selective? Re-evaluating some of the research. System, 39(4), 523-532.

Cid, E., Grañena, G. \& Tragant, E. (2009). Constructing and validating the foreign language attitudes and goals survey (FLAGS). System, 37(3), 496-513.

Council of Europe (2011). Common European Framework of Reference for Languages: Learning, Teaching, Assessment. Council of Europe.

Coyle, D. (2007). Content and Language Integrated Learning: Towards a connected research agenda for CLIL pedagogies. International Journal of Bilingual Education and Bilingualism, 10(5), $543-582$.

Coyle, D., Hood, P. \& Marsh, D. (2010). CLIL: Content and language integrated learning. Cambridge: Cambridge University Press.

Csizér, K. \& Dörnyei, Z. (2005). The internal structure of language learning motivation and its relationship with language choice and learning effort. The Modern Language Journal 89, 1936.

Dabbagh G, \& Khajehpour, M. (2011). Attitudes and motivation in learning English as second language in high school students. Procedia - Social and Behavioral Sciences, 15, 1209-1213.

Dalton-Puffer C. (2008). Outcomes and processes in content and language integrated learning (CLIL): Current research in Europe. In W. Delanoy \& L. Volkmann (Eds.). Future perspectives in English language teaching (pp. 7-23). Heidelberg: Carl Winter.

Deci, E. L., \& Ryan, R. M. (1985). Intrinsic Motivation and Self-Determination in Human Behavior. New York: Plenum Publishing Co.

Eurostat Newsrelease (2009). Proportion of female physicians, tertiary level academic staff and managers increasing, Release Date: 6 March 2009. Eurostat Press Office.

Fernández Fontecha, A. \& Terrazas Gallego, M. (2012). The role of motivation and age in vocabulary knowledge. VIAL, 9, 39-62.

Fernández Fontecha, A. (2010a). First Steps of CLIL in a Spanish Monolingual Community: The Case of La Rioja. In Y. Ruiz de Zarobe \& D. Lasagabaster (Eds.), CLIL in Spain: Implementation, Results and Teacher Training (79-94). Newcastle, UK: Cambridge Scholars Publishers.

Fernández Fontecha, A. (2010b). Gender and motivation in EFL vocabulary production. In R. M. Jiménez Catalán (Ed.), Gender perspectives on vocabulary in foreign and second languages (93-116). Houndmills, Basingstoke, Hampshire: Palgrave Macmillan.

Gardner, R. C. (1985). Social Psychology and Second Language Learning: The Role of Attitudes and Motivation. London: Edward Arnold.

Gardner, R. C. (2007). Motivation and second language acquisition. Porta Linguarum, 8, 9-20.

Gardner, R. C. \& Lambert, W. E. (1972). Attitudes and Motivation in Second Language Learning. Rowley, MA: Newbury.

Gardner, R. C., Lalonde, R. N., \& Moorcroft, R. (1985). The role of attitudes and motivation in second language learning: Correlational and experimental considerations, Language Learning, 35(2), 207-227.

Gobierno de La Rioja. (2004). Convocatoria de Proyectos de Innovación Lingüistica en Centros. Curso 2004/2004. Consejería de Educación, Cultura y Deporte. 19 May 2004.

Gobierno de La Rioja. (2005). Convocatoria de Proyectos de Innovación Lingüistica en Centros. Curso 2005/2006. Consejería de Educación, Cultura y Deporte. 19 May 2005.

Gobierno de La Rioja. (2009). Convocatoria de Proyectos de Innovación Lingüística en Centros. Curso 2009/2010. Consejería de Educación, Cultura y Deporte. 18 March 2009. 
Hartshorne, J. K. \& Ullman, M. T. (2006). Why Girls Say "Holded" More Than Boys, Developmental Science, 9(1), 21-32.

Henry, A., \& Apelgren, B. M. (2008). Young learners and multilingualism: A study of learner attitudes before and after the introduction of a second foreign language to the curriculum. System, 36(4), $607-623$.

Hernández, T. (2006). Integrative motivation as a predictor of success in the intermediate foreign language classroom, Foreign Language Annals, 39(4), 605-617.

Hyde, J. S. \& Linn, M. C. (1988). Gender differences in verbal abilities. A meta-analysis. Psychological Bulletin, 104(1), 53-69.

Instituto Nacional de Estadística (INE) (2010). Pruebas de Acceso a la Universidad. Año 2010. Retrieved from www.ine.es/prensa/np639.pdf, accessed 10 June 2012.

Jiménez, R. M. \& Moreno, S. (2004). L2 word associations and the variable sex: An outline according to an electronic tool. In A. Celada, D. Pastor García \& P. J. Pardo (Coord.), Actas del XXVII Congreso Internacional de AEDEAN. Salamanca: Servicio de Publicaciones de la Universidad de Salamanca.

Jiménez, R. M. \& Ojeda, J. (2008a). CLIL instruction and EFL learners' productivity in an availability task. Paper presented at the International CLIL Conference: CLIL fusion multilingual mindsets in a multicultural world. Building quality learning communities. Tallin, Estonia, October, 2425.

Jiménez, R. M. \& Ojeda, J. (2008b). The English vocabulary of girls and boys: Similarities or differences? Evidence from a corpus based study (pp. 103-115). In L. Litosseliti, H. Sauton, K. Harrington \& J. Sunderland (Eds.), Theoretical and Methodological Approaches to Gender and Language Study. London: Palgrave Macmillan.

Kiss, C. \& Nikolov, M. (2005). Preparing, piloting and validating an instrument to measure young learners' aptitude. Language Learning, 55(1), 99-150.

Kissau, S. (2006). Gender differences in motivation to learn French. Canadian Modern Language Review, 62(3), 401-422.

Lasagabaster, D. (2011). English achievement and student motivation in CLIL and EFL settings. Innovation in Language Learning and Teaching, 5, 3-18.

Lasagabaster, D. (2008). Foreign language competence in content and language integrated courses. The Open Applied Linguistics Journal, 1, 30-41.

Lasagabaster, D. (2003). Trilingüismo en la Enseñanza: Actitudes hacia la Segunda Lengua Minoritaria, la Mayoritaria y la Extranjera. Lleida: Editorial Milenio.

Lasagabaster, D. \& Sierra, J. M. (2009). Language Attitudes in CLIL and Traditional EFL Classes. International CLIL Research Journal, 1(2), 4-17.

Ludwig, J. (1983). Attitudes and expectations: A profile of female and male students of college French, German and Spanish. The Modern Language Journal, 67(3), 216-227.

Maitland, S. B., Herlitz, A., Nyberg, L., Backman, L. \& Nilsson, L. G. (2004). Selective sex differences in declarative memory. Memory and Cognition, 32, 1160-1169.

Masgoret, A-M. \& Gardner, R. (2003). Attitudes, motivation, and second language learning: metaanalyses of studies by Gardner and associates. In Z. Dörnyei, (Ed.), Attitudes, orientations and motivations in language learning (pp. 167-210). Oxford: Blackwell.

Mehisto, P., Marsh, D. \& Frigols, M. J. (2008). Uncovering CLIL: Content and Language Integrated Learning in Bilingual and Multilingual Contexts. Oxford: Macmillan.

Merisuo-Storm, T. (2007). Pupils' attitudes towards foreign-language learning and the development of literacy skills in bilingual education. Teaching and Teacher Education, 23, 226-235.

Mills, N., Pajares, F., \& Heron, C. (2007). Self-efficacy of college intermediate French students: Relation to achievement and motivation. Language Learning, 57(3), 417-442.

Mori, S. \& Gobel, P. (2006). Motivation and gender in the Japanese EFL classroom. System, 34(2), 194-210.

Murtagh, L. (2007). Out-of-school use of Irish, motivation to learn the language and proficiency in immersion and subject-only post-Primary programmes. International Journal of Bilingualism and Bilingual Education, 10(4), 428-453.

Noels, K. A. (2001). Learning Spanish as a second language: Learners' orientations and perceptions of their teachers' communication style. Language Learning, 51, 107-144. 
Noels, K. A., Pelletier, L.G., Clément, R., \& Vallerand, R. J. (2000). Why are you learning a second language? Motivational orientations and self-determination theory. Language Learning, 50, $57-$ 85.

Norton, B. (2000). Identity and Language Learning: Gender, Ethnicity and Educational Change. London: Pearson Education.

Oller, J. W., Hudson, A. J., \& Liu P. F. (1977). Attitudes and attained proficiency in ESL: A sociolinguistic study of native speakers of Chinese in the United States. Language Learning, 27, $1-27$.

Pérez-Vidal, C. (2009). The integration of content and language in the classroom: A European approach to education (the second time around) (pp. 3-13). In E. Dafouz, \& M. C. Guerrini (Eds.), CLIL across Educational Levels. Madrid: Richmond Publishing.

Phakiti, A. (2003). A closer look at gender and strategy use in L2 reading. Language Learning, 53(4), 649-702.

Scarcella, R. \& Zimmerman, C. (1998). Academic words and gender. ESL student performance on a test of academic lexicon. Studies in Second Language Acquisition, 20, 27-49.

Schmidt, R. \& Watanabe, Y. (2001). Motivation, strategy use, and pedagogical preferences in foreign language learning. In Z. Dornyei, Z. and R. Schmidt (Eds.), Motivation and second language acquisition (pp. 313-359). Honolulu, HI: University of Hawaii, Second Language Teaching Center.

Seikkula-Leino, J. (2007). CLIL learning: Achievement levels and affective factors. Language and Education, 21(4), 328-341.

Spolsky, B. (1989). Conditions for Second Language Learning. Oxford: Oxford University Press.

Stumpf, H. (1995). Gender differences in performance on tests of cognitive abilities: Experimental design issues and empirical results. Learning and Individual Differences, 7, 275-288.

Tremblay, P. \& Gardner, R.C. (1995). Expanding the motivation construct in language learning. Modern Language Journal, 79, 505-518.

Ullman, M. T. (2005). A cognitive neuroscience perspective on second language acquisition: The declarative/procedural model. In C. Sanz (Ed.), Mind and Context in Adult Second Language Acquisition: Methods, Theory, and Practice (pp. 141-178). Washington, DC: Georgetown University Press.

Ullman, M. T. (2004). Contributions of neural memory circuits to language: The declarative/procedural model. Cognition, 92(1-2), 231-270.

Ullman, M. T. (2001). The neural basis of lexicon and grammar in first and second language: The declarative/procedural model. Bilingualism: Language and Cognition, 4(1), 105-122.

Ullman, M. T., Miranda, R. A., \& Travers, M. L. (2008). Sex differences in the neurocognition of language. In J. B. Becker, K. J. Berkley, N. Geary, E. Hampson, J. P. Herman \& E. Young (Eds.), Sex on the Brain: From Genes to Behaviour (pp. 291-309). New York: Oxford University Press.

Vygotsky, L. S. (1978). Mind in Society. Cambridge, MA: Cambridge University Press.

Wigfield, A., Eccles, J. S., Schiefele, U., Roeser, R. W. \& Davis-Kean, P. E. (2006). Development of achievement motivation. In N. Damon \& R. M. Lerner (Eds.), Handbook of Child Psychology, Vol. 3: Social, emotional, and personality development (pp. 933-1002). Hoboken, NJ: John Wiley \& Sons Inc.

Wikeley, F. \& Stables, A. (1999). Changes in school students. Approaches to subject option choices: A study of pupils in the West of England in 1984 and 1996. Educational Research, 41, 287-299.

Yu, B. \& Watkins, D.A. (2008). Motivational and cultural correlates of second language acquisition: An investigation of international students in the universities of the People's Republic of China. Australian Review of Applied Linguistics, 31(2), 17.1-17.22. 